\title{
Islamic Microfinance and Its Impacts on Borrowers: A Systematic Review From 1995-2015
}

Shamsuddin Ahamad

Graduate Assistant, University Malaysia Perlis; Correspondent authors and Email: shamsuddin.cu@gmail.com

\author{
Dr. Rosni Bakar
}

Professor. University Malaysia Perlis, Email: rosnibakar@gmail.com

\section{Dr. Zulkarnain Lubis}

Professor, University Malaysia Perlis, Email: hzulkarnain@unimap.edu.my

\section{Doi:10.5901/mjss.2016.v7n6p113}

\section{Abstract}

\begin{abstract}
Islamic microfinance is being an ever more important instrument in fighting rural poverty in many countries. It has been trying to improve the welfare of the poor people through increasing their level of income, expenditure on consumption and improving the overall living standard. This study is, therefore, aims to survey the impact of Islamic microfinance on borrowers. By using systematic literature review, this study provided a descriptive analysis of the gathered articles. Then a comprehensive analysis on the impact of Islamic microfinance executed. This study also provided a summary of the existing prominence of work by systemized way. Further, this study focused on the areas of lacking for further study and explained the importance of the study.
\end{abstract}

Keywords: Islamic Microfinance, Microcredit, Impact, Factors, Systematic Review.

\section{Introduction}

Over the two decades, Islamic microfinance (IMFs) has been socio-economic development approach besides the conventional microfinance in many countries. Islamic Microfinance Institutions (IMFIs) providing financial services, including credit saving and insurance through institutions, to low-income clients, where the market fails to provide appropriate services. Some IMFIs also providing communal intermediation services such as education and training, health and skill, and organizational support in line with their development objectives. IMFs is now becoming a rapidly growing market with this objective and their development approach, offering millions of disadvantaged people in many countries and beyond access to financial services that are premised on providing for the welfare of the population. Muslim people are very interested in receiving interest-free microfinance loan. Besides this situation, the literature shows that comparison with conventional microfinance, Islamic MFs is still lag behind in a number of clients (Khaled 2011, and Obaidullah, 2008). As a development intervention, there is also a lack of rigorous assessments of the impact of IMFs programs. An inclusive examination of the impact of IMFs is necessary because it can help to improve the performance of this sector. Also increasing the performance of the IMFs industry it is a very important task since it can help more poor people gain both access to financial services and benefits from these services.

The present study aims to review, analyze and synthesize the extant body of literature on the impact of Islamic Microfinance by providing a systemic literature review of empirical articles. This supports this study to understanding, what factors of Islamic Microfinance have been studied so far, what types of performance it can lead to, and what areas are still lacking rigorous investigation. Second, then most importantly recommended that in future, where effort should be emphasized.

This study is, therefore, organized as follows: first literature review in section two. Second, overall review process presented and the review protocol in section three. Described the results of the review in section four and continue towards the conclusion in section five with the prospect of future research on Islamic Microfinance.

\section{Literature Review}

Microfinance programs generally projected for the overall improvement of life standard and wellbeing of Borrowers. 
Primarily, it has been designed for the poor people to access the formal financial system easily without any collateral. With this aim, microfinance raises borrowers' income, consumption expenditure and reduces poverty. Beside this, microfinance also provides social services like primary education, child education, health awareness, hygiene, disease prevention, and the women empowerment (Khandker, 2005, Mehjabeen, 2008).

The literature on impact studies of microfinance shows that microfinance helps the poor borrowers to improve their living standard. For example, Morduch (1999) found that borrowers' income increased five times from \$1 finance. Karlan and Zinman (2010) found in South African studies, that household who receive a loan, their poverty decreased and in Manila studies in 2009 shows that borrowers' welfare improved. The findings also show that the impact of savings is normally positive because savings tend to help smooth consumption patterns, and they also help poor households to accumulate working capital. Moll (2005) studied the effect of microfinance on household impact studies. The author highlighted three aspects to assess the impact; saving mobility, consumption expenditure to adequate the food intake and invest the loan in income generating activities. Pitt and Khandker (1998), also assess the consumption trend of borrowers and found a positive impact on consumption expenditure.

Microfinance also focused on women. Literature shows that women are empowered in terms of involvement in income generating activities, the capability to spend for family, assets ownership and decision-making ability (Hashemi et all, 1996, Cheston and Kuhn 2002, Nader, 2008). This improvement ultimately enables women borrowers to improve their child education and awareness of health etc. Consequently, this evidence indicates that microfinance has become a success to help a huge number of poor peoples (Morduch and Haley, 2002). Therefore, microfinance borrowers' welfare improvement was defined as those who had improved their income, assets, their child education, health, increasing assets, living standard and who are able to repayment the loan etc.

\section{Methods}

To stipulating the methodological details of the study, it is essentials to see the importance of a systemic review. Fink, 1998 and Hart, 1998 advocate that, the system of the typical literature review is often criticized because of their personal, subjective and biased methodology. To come out from this situation, a systematic review methodology was proposed by Transfield et al. in 2003. The authors argued that this methodology is more suitable to reduce the chance effect and increase the acceptability of the following evidence. The systematic review also provides reliable result which helps to draw a conclusion and assist in making decisions.

A systematic review is therefore defined as a methodological process and summary of research that uses explicit methods to perform a detailed literature search to identifies, evaluates and analyzes the valid and applicable evidence (Kitchenham, 2004; Staples \& Niazi, 2007; Mohiuddin, 2011). As the present paper aims to review, analyze and synthesize the extant body of literature on the impact of Islamic Microfinance, the authors logically set this method.

However, in order to gather a most suitable set of articles, the following procedures were followed: the search started with a broad prospection of articles; then went to a couple of steps in which first assessed the content of articles retrieved and secondly refined the selection criteria. The process repeated these two steps as long as were unsatisfied with the match between research objective and the articles found. This procedure is detailed in below.

Five databases were used to gather articles: Emerald Management Premier, Springer Link e-journals, Science Direct, Jstore, Wiley Online Library and Google Scholar described in Table: 1.

Table-1: Selected online databases for the literature search

\begin{tabular}{|c|c|}
\hline Online Databases & Subject Focuses \\
\hline $\begin{array}{ll}\text { - } & \text { Emerald Management } \\
\text { - } & \text { Springer Link } \\
\text { - } & \text { Science Direct } \\
\text { - } & \text { Jstore } \\
\text { - } & \text { EBSCO HOST } \\
\text { - } & \text { Google Scholar }\end{array}$ & $\begin{array}{l}\text { Impact, Microcredit, } \\
\text { Islamic Microfinance }\end{array}$ \\
\hline
\end{tabular}

This study covered a twenty years' time period, from the beginning of January 1995 to the end of Jun 2015. Articles gather as many as possible was the first step of this study. A broad taxonomy used to gather articles. Following Table 2 describe the process of selecting articles. 
Table 2: Articles Selection Process

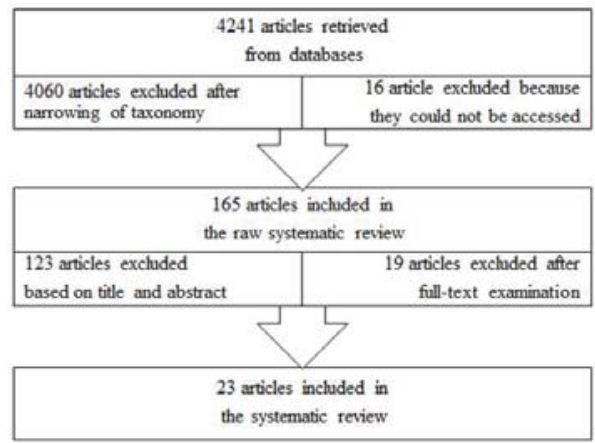

As an emerging sector to alleviate the poverty from society and country, it is important to see the impact of IMFs based on countries. Islamic microfinance Institute (IMFIs) is working in a lot of countries besides the conventional microfinance. As the present research is focusing on the impact of IMFs globally, so it is necessary to highlight the performance of the program according to a country described in graph 1 . The online search explored that most of the research conducted in Bangladesh and Malaysia accordingly $22 \%$ and $17 \%$ where Indonesia is $9 \%$, Sri Lanka is $9 \%$, Pakistan is $9 \%$, Nigeria is $4 \%$ and India is $4 \%$. 22\% research conducted jointly within two and three countries. As the objective of this research is to examine the impact of IMFs so it considered all countries globally for research findings.

Graph:1 Distribution of Publication

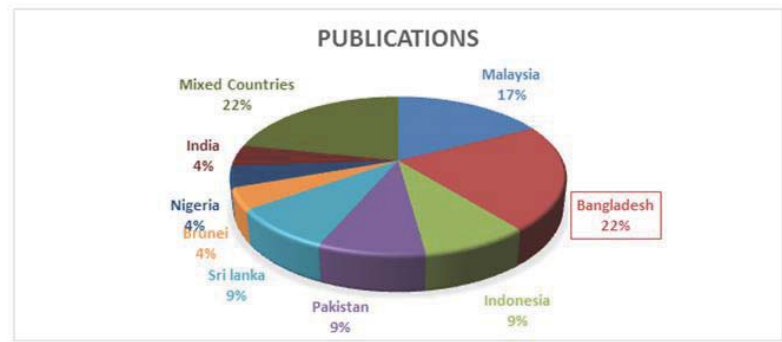

In the case of time-based of publication, following Graph: 2 shows a trend of literature according to year. It can be seen that the year 2013 represents the highest publication which is $30.43 \%$. The present research considered from January 1995 to April 2015 but did not get in depth articles on impact studies of IMFs before 2002. Islamic Microfinance came later comparative to conventional microfinance. Particularly after 1995 formally IMFs introduced and for that reason usually the research trend on impact studies found from 2002. Therefore, from 2010, it is raising globally.

Graph: 2 Time-Based Trend of Publication

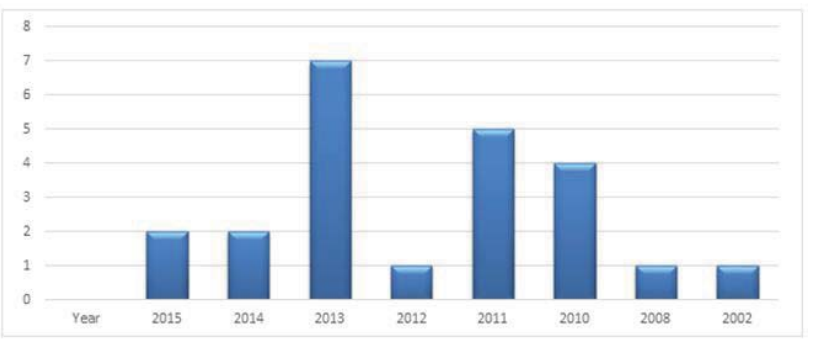




\section{Findings}

In order to achieve the Sustainable Development Goals (SDG), it is one of the most important concern to reach the vast majority of the poor people to alleviate their poverty from the world. Over the years, IMFs is trying to improve their borrowers' welfare through increasing income level, expenditure on consumption and improving the overall living standard etc. To find out the existing scenario of improvement, this study set initial research objective is to highlight the impact of IMFs on borrowers. The following section 3.1 explain the findings of studies on IMFs borrowers. Section 3.2 explain the factors affecting the impact on borrowers.

\subsection{Impact Studies on IMFs Borrowers}

Impact evaluation is an important issue to see the particular intervention of instantiations that they made a change. As a development partner, microfinance program intervention has been designed for the poor people without collateral. Therefore, Islamic microfinance institutions are not only financial institutions but also contributing for the poor people more for improving their standard of life. Their objective is to improve the borrower's status. For impact studies, this study considered the income level of borrowers, as well as expenditure and overall welfare.

\subsubsection{Impact on Income and Consumption Expenditure}

Income and expenditure on consumption are the main indicators for the improvement of poor people's living standard. Literature shows that IMFs is trying to increase their income and expenditure on consumption. An effectiveness study on Baitul Maal wat Tamwil (BMT) in Indonesia, Adnan \& Ajija (2015) found that BMT financing is effective in increase their income after receiving BMT financing. Jariya (2013) found from Sri Lanka studies on Islamic Relief microfinance project that beneficiaries have generated incomes with new projects receiving microfinance and increased their income. The authors also found that they are spending this income for purchasing food for their family. Zaidah (2011) conducted a study to identify the effectiveness of the Amanah Ikhtiar Malaysia (AIM) program in reducing poverty among low-income households in rural areas in Malaysia and the results of studies found that income of AIM members has an increase after they joined AIM program. Samir et. All (2015) also conducted a study on the same institution and same country. The authors also found a positive impact on household income. Saad and Duasa (2010), Hamdan et. All (2012) also found the same result on their study on same IMFIs.

Rahman and Ahmad (2010) studied the impact of microcredit clients of Rural Development Scheme (RDS) of Islami Bank Bangladesh Ltd. The authors found that household income significantly increased. The authors also found that micro-investment program had a significant and positive contribution to the household's food expenditure and total expenditure. Bhuiyian et. All (2013), Uddin (2008), Ahmad (2002), also studied the impact on same countries and same IMFIs. The authors found that RDS microfinance borrowers are using the loan to increase their income. Their research revealed that IMFIs' funds have been successful in increasing the living conditions of their beneficiaries.

Morshid and Abdullah (2013) study is argued that the IMFIs project, JAPEM of Brunei is highly effective in increasing the clients' number of business assets but the institution is not effective in terms of increasing the clients' income. The research findings of Widiyanto (2010) in Indonesia and Hassan, A. (2014) in India is that IMFs improved the household income. Ullah et. All (2011), Khan and Usman (2010) found that Islamic Relief Pakistan microfinance scheme successes to increase the borrower's income. The authors also found that Islamic relief's borrowers' family expenditure significantly increased.

\subsubsection{Impact on IMFs Borrowers Welfare}

Islamic Microfinance programs generally projected for the overall improvement of life standard and wellbeing of Borrowers. Worldwide, Islamic microfinance program is designed for the people who are not able to entrance in the formal financial system. They also provide social services like basic education, child education, health awareness, hygiene, sanitation, and pure water etc. With these services, microfinance institutes are trying to improve the quality of life and reduce the poverty of poor peoples. This improvement ultimately enables borrowers to improve their child education and awareness of health and overall welfare. Microfinance borrowers' welfare improvement was defined as those who had improved their child education, health, increasing assets, living standard and who are able to repayment the loan etc.

Jariya (2013) found from Sri Lanka studies on Islamic relief microfinance project that beneficiaries had been able to change their standard of living. Uddin (2008) examined the impact of RDS of IBBL on the socio-economic development of 
its members. The author found that RDS positively make an impact in the case of food intake, child education, housing, clothing, medical treatment, use of clear pure water, use of the toilet. Rahman and Ahmad (2010) studied on the same IMFIs and found that RDS investment significantly contributed to their borrower's well-being. In the same institution studies, Bhuiyan (2013) also observed that borrower's wellbeing and sustainable livelihood improved after joining the program. The author also observed that borrowers increased their overall self-confidence, personal responsibility for the family, self-capability of solving their own problems and send their children to school.

Ullah (2011), Khan and Usman (2010) found in Islamic Relief, Pakistan studies that Islamic microfinance project positively improved the welfare of the clients. Hamdan et. All (2012) found that Islamic microfinance program of AlM in Malaysia enables the poor people to increase their household income and improve their social well-being.

\subsection{Factors Affecting on IMFs Borrowers}

This study explored the factors affecting on microfinance borrowers from a systematic review. To find out the factors, different types of analyses technique are used. From the analysis of literature, it is found that descriptive statistics is widely used. As shown in the graph 3, 44\% of the reviewed article used this method.

Graph 3: Statistical Technique Used to Study Impact of IMFs

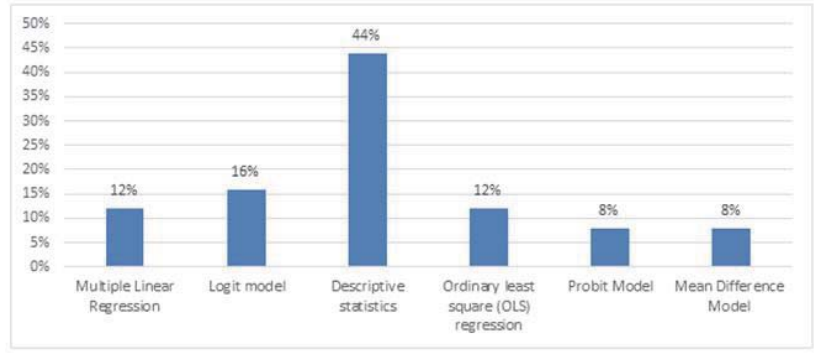

Logit model, Multiple Linear Regression and OLS model also used accordingly $16 \%$ and $12 \%$ to find out the impact on income, expenditure, welfare with factors. Many researchers used many factors such as the size of the loan, time duration, training, borrower's demographic factors such as age, education level, marital status, etc. described in below and trend of studies in graph 4.

\subsubsection{Size of Loan}

The amount of loan is the main important tool to run a business successfully. But the poor people often suffer for sufficient loan. Hamdan et. All (2012) found in their study on AIM in Malaysia that the loan size is the main factor which influences to increase income. Saad \& Duasa (2010) also found that total amount of loan borrowings from AlM positively and significantly increased borrowers' per capita income and consumption. Rahman and Ahmad (2010) studied the impact of microcredit clients of RDS of Islami Bank Bangladesh Ltd. The authors found that loan size play rule to increase income and it leads to the household welfare. Further, the authors suggested that size of investment has to be optimum and timely.

\subsubsection{Time with Microfinance}

The longer of the work experience of the clients tend to generate higher business income (Hamdan, 2012). In Indonesia studies, Rulindo and Pramanik (2013) found that clients having a longer duration with Islamic microfinance have a greater possibility of having better business and having a higher income as well as live in better economic condition. Rahman \& Ahmad (2010) studied the impact of microcredit clients of RDS of Islami Bank Bangladesh Ltd. The authors found that time duration with RDS significantly contributed on clients' well-being. The findings revealed that borrowers are able to improve their socioeconomic status through long time involvement with the Islamic microfinance program. Khan (2010) and Ullah (2011) found in Pakistan that clients who avail the facility of microfinance for more time they have been able to increase his/her welfare. 


\subsubsection{Training}

Training is related to the efficiency. Karlan and Validivia (2007) indicated that those borrowers who receive training from microfinance institutes they can show better performances. Morshid and Abdullah (2013) mentioned that the borrowers are interested in learning more about their business field by training. Rahman and Ahmad (2010) studied the impact of microcredit clients of RDS of Islami Bank BD Ltd. The authors found that training is important for ensuring the borrower's income generating activities and welfare. Sameer et all (2015) found in Malaysia that household income is positively influenced by training.

\subsubsection{Morality and Religiosity}

Moral and religious development is also the important factor for the welfare of borrowers of Islamic microfinance. It is also a most important agenda of IMFs. Rahman et.all (2010) argued that the borrowers who are ethically and morally good, they are honest to back their loan. This kind of people does not misuse the loan. Ashraf (2010) argued that the religious restriction has a positive significance impact and this factor influence to the microfinance consumers' to their overall satisfaction. The IMFs program has provided the clients the opportunity to develop their ethics and morality. Ethics and morality have a positive and significant influence on overall household improvement. The IMFs program provide a better opportunity to their clients to run their business more organized way and help them to maintain a good quality life with following the ethics and morality (Rahman et. all, 2010). Moreover, as microcredit program of IMFs, moral and religious development is an important factor for study.

Rulindo and Pramanik (2013) found from Indonesian IMFIs study that higher spiritual and religious people have the bigger possibility to have better subjective poverty status. In term of the poverty level, clients who have higher religiosity level have the possibility of living over poverty line by 0.5 times as compared others. The authors mentioned that Islamic teachings give values such as honesty, sincerity, discipline and hard work which is the result of doing worships such as salat, fasting etc. An ilnteresting finding is found for spirituality. Although there is no significant association between levels of spirituality to income of micro-entrepreneurs, the higher spiritual people are wealthier as they have greater possibilities to live over the poverty line especially when the status is measured by household income as a benchmark of poverty line income.

\subsubsection{Age of Borrowers}

Age is related to the experience. To perform a job, the age of an individual is a vital factor. Saad \& Duasa (2010) measured the economic performance of clients participating in the IMFs program of AIM in Malaysia and found that older clients tend to earn higher incomes from the AIM program. Samer et all (2015) also found the same result of their study that age have a positive impact on women household income. Rahman and Ahmad (2010) studied the impact of microcredit clients of RDS in Bangladesh. The authors found that borrower's played a role in increasing income. Furthur, they mentioned that the aged people are experiencing and they can help business more to increase their household income. Khan (2010) and Ullah (2011) found from their empirical investigation in Pakistan that if the loan is provided to the 40 or more age's clients this will increase their income and social welfare. On the other hand, Uddin, (2008) argued that comparatively, young age person is better to put dedication, willingness, and importance to be success in business

\subsubsection{Education Level}

Education of a people is important to reducing poverty and wealth creation. Education of a people helps them to invest their fund efficiently and profitably. It is a vital factor for poor people to gain better outputs in rural areas. In the study of AIM in Malaysia to measure the economic performance of borrowers, Saad \& Duasa (2010) found that higher educated borrowers are correlated with higher income after respondents participated in AIM activities. Samer et all (2015) also found the same result of their study that education level of borrowers has a positive impact on women household income. The authors indicated that it is expected, more educated clients are more knowledgeable in handling their projects. Rahman and Ahmad (2010) studied the impact of microcredit clients of RDS in Bangladesh. The authors found that the level of education of borrowers influences to their income. Khan (2010) found from their empirical investigation in Pakistan that education level of clients increases the chance in income and favor of social wellbeing. 


\section{Conclusion and Future Avenue of Research}

The particular objective of this study was to examine the existing literature on the impact of Islamic Microfinance. This study concentrated on a twenty years', January 1995 to Jun 2015. A total of twenty-three articles were collected which were very linked to the subject. After examination, these articles enabled us to conclude the strengths and gaps on the impact of Islamic Microfinance. From the overall review, this research found that IMFIs is very effective to increase borrower's income, expenditure and borrowers welfare. This study also gave supports to understanding what factors of Islamic Microfinance have been studied so far. Therefore, besides this scenario there are still lacking rigorous investigation described below:

From the literature, it is found that most of the impact studies conducted on the borrower's household level and individual level. This study found a positive impact on those level. Therefore, impact on borrower's business improvement can be another field. Rigorous Investigation can be done together such as individual, household, and business. Loan Repayment is the one of three (Joint liability, Small installment payments, Dynamic incentives) basic characteristics of microcredit programs (Guttman, 2007). Repayment of microcredit loan is one of an important question in microfinance. It can be the field for the future research in the Islamic microfinance field.

Microfinance loans on poor and non-poor separately could be measure. The microfinance institutes provide a loan to a borrower who live around their branches and where the easy communications available. But most of the hardcore poor people live away from such mentioned area and the communication of that area often critical. For these reasons, it is important to see the contribution of exciting microfinance institutes for hard-core poor people.

A systematic review showed that most of the IMFs loan program has been able to improve borrower's living status. It is important to find out that why others people do not. Microfinance also formed for employment creation. There is a lack of impact study on employment creation opportunity through IMFs.

Therefore, the overall impact study revealed that some of the research led to see the economic impact of borrowers and some of them on social impact. Besides these studies, the large-scale study on microeconomic impact can bring a large scenario of IMFIs impact in the field of economics studies.

\section{References}

Adnan, M. A., \& Ajija, S. R. (2015). The effectiveness of Baitul Maal wat Tamwil in reducing poverty: the case of Indonesian Islamic Microfinance Institution. Humanomics, 31(2).

Ahmed, H. (2002). Financing microenterprises: An analytical study of Islamic microfinance institutions. Islamic Economic Studies, 9(2), 27-64.

A.M. Inun Jariya (2013). True Economy Prosperity through Poverty Alleviation-Islamic Microfinance as Commercial Venture ProceedingKuala Lumpur International Business, Economics and Law Conference.

Ashraf, M. A. (2010). The Effectiveness of Microcredit Programs and Prospects of Islamic Microfinance Institutes (IMFIs) in Muslim Countries: A Case Study of Bangladesh. Journal of Islamic Economics, Banking and Finance, 6(4), 32-45.

Bhuiyan, A. B., \& Hassan, A. (2013). Microcredit and Sustainable Livelihood: An Empirical Study of Islamic and Conventional Credit on the Development of Human Capital of the Borrowers in Bangladesh. Journal of Economic Cooperation and Development, 34(3), 101-128.

Bin Mislan Cokro Hadisumarto, W., \& Ghafar B. Ismail, A. (2010). Improving the effectiveness of Islamic micro-financing: Learning from BMT experience. Humanomics, 26(1), 65-75.

Cheston, S., \& Kuhn, L. (2002). Empowering women through microfinance. Draft, Opportunity International.

Cook, D. J., Mulrow, C. D., \& Haynes, R. B. (1997). Systematic reviews: synthesis of best evidence for clinical decisions. Annals of internal medicine, 126(5), 376-380.

Fink, A. (1998). Conducting research literature review: from paper to the internet.

Guttman, M. J. (2007). Repayment performance in microcredit programs: theory and evidence. Networks Financial Insititute, Indiana University. Working paper, 11.

Hamdan, H., Othman, P., \& WSW, H. (2012). Is microfinance program in Malaysia really effective in helping the poor? World Review of Business Research, 2(1), 79-97.

Hassan, A. (2014). The challenge in poverty alleviation:the role of Islamic microfinance and social capital. Humanomics, 30(1), 76-90.

Hashemi, S. M., Schuler, S. R., \& Riley, A. P. (1996). Rural credit programs and women's empowerment in Bangladesh. World development, 24(4), 635-653.

Hart, C. (1998). Doing a literature review: Releasing the social science research imagination. Sage.

Karlan, D., \& Zinman, J. (2010). Expanding microenterprise credit access: Using randomized supply decisions to estimate the impacts in Manila. Innovations for Poverty Action working paper.

Khan, Z., \& Usman, M (2010). Financing non Bankable Masses: An Analytical Study of Conventional Verses Islamic Microfinance Programs (Lesson from Muslim World). 
Khaled, M. (2011). Building a Successful Business Model for Islamic Microfinance. CGAP, New York.

Khandker, S. R. (2005). Microfinance and poverty: Evidence using panel data from Bangladesh. The World Bank Economic Review, 19(2), 263-286.

Kitchenham, B. (2004). Procedures for performing systematic reviews. Keele, UK, Keele University, 33(2004), 1-26.

Mahjabeen, R. (2008). Microfinancing in Bangladesh: Impact on households, consumption, and welfare. Journal of policy modeling, 30(6), 1083-1092.

Md Saad, N., \& Duasa, J. (2010). Determinants of economic performance of micro-credit clients and prospect of Islamic microfinance in Malaysia. ISRA International Journal of Islamic Finance, 2(1), 113-130.

Mizanur Rahman, M., \& Ahmad, F. (2010). Impact of microfinance of IBBL on the rural poor's livelihood in Bangladesh: an empirical study. International journal of Islamic and Middle Eastern finance and management, 3(2), 168-190.

Mohiuddin, M. (2011). Research on Offshore outsourcing: A systematic literature review. Journal of International Business Research (JIBR), 10(1), 57-76.

Morshid N, Abdullah R, (2013) The Effectiveness of Islamic Microfinance in Brunei Darussalam: A Case Study Paper presented the $5^{\text {th }}$ Islamic Economic System Conference organized by USM

Morduch J (1999), "The microfinance promise," Journal of Economic Literature, 37, 1569-614

Morduch, J., \& Haley, B. (2002). Analysis of the effects of microfinance on poverty reduction (Vol. 1014). NYU Wagner Working Paper.

Moll, H. A. J. (2005). Microfinance and rural development: a long-term perspective. ESR Review, 7(2), 13.

Nader, Y. (2008). Microcredit and the socio-economic wellbeing of women and their families in Cairo. The Journal of Socio-Economics, $37(2), 644-656$.

Obaidullah, M. (2008). Introduction to Islamic Microfinance, IBF Net Limited.

Pitt, M., \& Khandker, S. (1998). The impact of group-based credit programs on poor households in Bangladesh: Does the gender of participants matter?" Journal of political economy, volume 106, (issue 5), 958-996.

Rahman, A. R. A. (2010). Islamic microfinance: an ethical alternative to poverty alleviation. Humanomics, 26(4), 284-295.

Rahman, M. T., \& Khan, H. T. (2013). The effectiveness of the microcredit programme in Bangladesh. Local Economy, 28(1), 85-98.

Rulindo, R., \& Pramanik, A. H. (2013). Finding a Way to Enhance Impact of Islamic Microfinance: The Role of Spiritual and Religious Enhancement Programmes. Developing Country Studies, 3(7), 41-52.

Samer, S., Majid, I., Rizal, S., Muhamad, M. R., \& Rashid, N. (2015). The Impact of Microfinance on Poverty Reduction: Empirical Evidence from Malaysian Perspective. Procedia-Social and Behavioral Sciences, 195, 721-728.

Staples, M., \& Niazi, M. (2007). Experiences using systematic review guidelines. Journal of Systems and Software, 80(9), $1425-1437$.

Tranfield, D. R., Denyer, D., \& Smart, P. (2003). Towards a methodology for developing evidence-informed management knowledge by means of systematic review. British journal of management, 14, 207-222.

Uddin, M. M. (2008). Credit for the Poor: The Experience of Rural Development Scheme of Islami Bank Bangladesh Ltd. Journal of Nepalese Business Studies, 5(1), 62-75.

Ullah A, Khan Z, \& Yasin H.M (2011). Cooperative Microfinance Myth or Reality: An Economic Analysis of the Welfare of Marginalized Segments. 8th International Conference on Islamic Economics and Finance

Valdivia, M., \& Karlan, D. (2006). Teaching Entrepreneurship: Impact of Business Training on Microfinance Clients and Institutions (No. 941). Center for global development, working paper no 107.

Zaidah, N., \& Nor, C. M. (2011). The Effectiveness of Amanah Ikhtiar Malaysia (AIM) in Reducing Rural Poverty: A Case Study of Pokok Sena 